\title{
Obituaries
}

Editor: Henry R. Rollin

\section{Norman Cranston Low, formerly Consultant Psychiatrist, Carlton Hayes Hospital, Narborough, Leicester}

Norman Cranston Low died at his home in Leicester on 20 July 1993, aged 69, after a long and distressing illness which he bore with remarkable courage.

Dr Low was born in 1924 in Edinburgh, the only son of the late Dr Robert Cranston Low, the eminent dermatologist. He attended Edinburgh Academy and then followed his father into medicine, also qualifying in Edinburgh. After house officer posts at the Edinburgh Royal Infirmary he moved into psychiatry, training under Professors Sir David Henderson and Alexander Kennedy. Following service in the RAMC, in which he rose rapidly to the post of Command Psychiatrist, with the rank of major, he returned to Edinburgh. He was then appointed to Rauceby Hospital, Lincolnshire, and subsequently as consultant to Carlton Hayes Hospital, Leicester in 1963. He was elected a Foundation Member of the Royal College of Psychiatrists in 1971 and proceeded to the Fellowship in 1982. Early in his career he developed a special interest in forensic psychiatry and was appointed by the Home Office as visiting consultant to Gartree Prison and Glen Parva Borstal. Following his retirement in 1989 he was appointed to the Parole Board.

Alongside his professional activities Dr Low was a man of wide culture and achieved some prominence in the City, being at various times President of the Leicester Lions Club and of the Leicester Antiques Society. He was an avid reader of historical biography and a keen musician. With his powerful baritone voice, he sang in the Leicester Philharmonic Choir and was an ardent and knowledgeable opera-goer. He became senior warden of one of Leicester's most notable churches and was a member of a panel of advisers to the Bishop of Leicester on social matters.

He was sustained throughout his illness by his strong religious faith, his loving family and his many friends. He leaves his wife Pamela, a son, three daughters and eight grandchildren.

NORMAN KAYE

\section{Brian Hunt Vawdrey, formerly Consultant Psychiatrist, Graylingwell Hospital, Sussex}

Brian Vawdrey was born in November 1918 at Limpsfield, Surrey. After preparatory school he went on to Tonbridge where he did well both academically and at games and then went up to Pembroke College Cambridge and subsequently on a scholarship to St Thomas' Hospital. He qualified MRCS LRCP in January 1944, and took his Cambridge MB in June of that year.

From St Thomas' Brian was commissioned in the RAMC for his National Service and served in the Far East and Port Said, attaining the rank of major. After demobilisation Brian joined a general practice in Balcombe for some three years before his interest in psychiatry took him to Edinburgh (it was here that he met and married Ethel). He remained in Edinburgh for three years, where he gained the DPM. He was awarded the MD at Cambridge, writing his thesis on Art Therapy in Psychiatry. It was during this time that he became interested in psychotherapy and trained in the Jungian school.

In 1954 Brian was appointed Senior Registrar at Graylingwell and it was then that I first met him. My own appointment to Hellingly in December 1955 limited my period of working directly with him. However, he took over from me as consultant to what was then Chichester \& Bognor Regis Marriage Guidance Council and he continued in this role through a series of changes and reorganisations. Brian remained on the staff of Graylingwell until his retirement from the NHS in 1985, becoming a consultant in the '60s. He was elected a foundation member of the Royal College of Psychiatrists in 1971.

After retirement from the NHS he continued in private work. He served as medical member on Mental Health Review Tribunals and continued as consultant to Ravenscroft Alcoholic Unit, Bognor, to the Offington Counselling Centre, Worthing and to Arun Counselling Service. In addition, Brian took a great interest in forensic psychiatry and many is the time, when I was consultant to HM Prison Lewes, that he was called on for an opinion.

$\mathrm{He}$ is survived by his wife, Ethel and his five children to whom our sympathies are extended.

DAVID RICE 